\title{
Luther Today
}

\section{A. Yu. Prokopiev}

For citation: Prokopiev A. Yu. Luther Today. Vestnik of Saint Petersburg University. History, 2018, vol. 63, issue 2, pp. 648-659. https://doi.org/10.21638/11701/spbu02.2018.219

The article examines main works by German and European historians specializing in the biography and public activity of the Reformer Martin Luther. The focus is primarily on the works by historians Heinz Schilling and Volker Leppin, placed in the context of modern historiographical discussion. How can the phenomenon of Luther be interpreted in a methodologically constructive way, how significant can be the research of the anthropology of the personality and a wider socio-structural scope of examination? The possibilities and limitations of the application of certain concepts to the phenomenon of Luther, in particular, the concept of confessionalization most consistently represented by Heinz Schilling, are illustrated in the paper. Besides that, the author elaborates on the mystical roots of Luther's theology in Volker Leppin's representation. The article also focuses on the aspects of continuity and differences between certain recent areas of research. An advanced approach of historical anthropology in Volker Leppin's works is discussed together with civilizational notions in the books by Thomas Kaufmann and Heinz Schilling. Schilling's book is exceptionally significant as it perceives the phenomenon of Luther from a viewpoint of the concept of confessionalisation, whose representative Shilling is. The origins of the Reformation and the development of Luther as a theologian were affected by the factors of a previous period. As far as this aspect is concerned, Volker Leppin's research is of special interest. The author carries out an in-depth study of the connection between spiritual origins of the Reformer and the ideas of his older contemporaries and predecessors.

Keywords: Luther, historiography, Reformation, Germany, evangelical church, confessionalization.

\section{Лютер сегодня}

\section{А.Ю. Прокопьев}

Для цитирования: Prokopiev A. Yu. Luther Today // Вестник Санкт-Петербургского университета. История. 2018. Т. 63. Вып. 2. С. 648-659. https://doi.org/10.21638/11701/spbu02.2018.219

В статье рассматриваются основные работы немецких и европейских историков, занимавшихся биографией и общественной деятельностью реформатора Мартина Лютера. В центре внимания автора статьи - преимущественно труды Хайнца Шиллинга

Andrei Yu. Prokopiev - Doctor in History, Professor, St. Petersburg State University, 7-9, Universitetskaya nab., St. Petersburg, 199034, Russian Federation; a.prokopiev@spbu.ru

Андрей Юрьевич Прокопьев - д-р ист. наук, проф., Санкт-Петербургский государственный университет, Российская Федерация 199034, Санкт-Петербург, Университетская наб., 7-9; a.prokopiev@spbu.ru

The article was written with the financial support of the Russian Foundation for the Humanities (project: 17-01-00121 "Europe in the era of the Reformation and Counter-Reformation: diplomatic correspondence of European households of the 16 - first half of the 17 centuries".

(c) Санкт-Петербургский государственный университет, 2018 
и Фолькера Леппина, помещенные в контекст современной историографической дискуссии. Как методологически продуктивно можно было бы истолковать феномен Лютера? Какое значение может иметь исследование антропологии личности и более широкий социоструктурный охват? Подчеркивается значение историко-антропологического поворота в немецкой и европейской исторической науке в конце XX в., позволившего с новых позиций осветить истоки формирования Лютера как реформатора и его судьбы. Показаны возможности и границы в употреблении к феномену Лютера новых концепций, в частности концепции конфессионализации, особенно последовательно представленной в работах Хайнца Шиллинга. Дается подробный анализ мистических корней теологии Лютера в представлении Фолькера Леппина. Углубленный историко-антропологический подход, отраженный в трудах Фолькера Леппина, соседствует с более общими, цивилизационными воззрениями в трудах Томаса Кауфмана и Хайнца Шиллинга. Работа Шиллинга особенно важна, поскольку содержит видение феномена Лютера сквозь призму концепции конфессионализации, одним из авторов которой является сам Шиллинг. Впрочем, слишком большой охват материала, цивилизационный угол зрения влекут не всегда равномерное освещение личности самого Лютера, его духовных корней. Фигура реформатора заслоняется глобальными общественно-политическими процессами. Труд Шиллинга несомненно концептуален, но оставляет немало вопросов. Его следует рассматривать как крупный справочник по различным сторонам жизни эпохи, Лютер выступает в его биографии лишь как одно из многих действующих лиц. В целом же сегодня больше заметно желание историков видеть в Лютере наследие прошлого, влияние средневековой традиции. Сама Реформация предстает не спонтанным рождением нового мира, а сложным духовным и социальным явлением, подготовленным в позднее Средневековье. Ее истоки, формирование Лютера как богослова прошли под сильнейшим влиянием факторов предшествовавшего времени.

Ключевые слова: Лютер, историография, Реформация, Германия, Евангелическая церковь, конфессионализация.

It is hardly surprising to see the abundance of German scholarly works reflecting on the phenomenon of Luther in the year of the jubilee of the Reformation. Remarkably, books by two generations of historians - of the $20^{\text {th }}$ century and of our century - are presented together on the book counters. It has been forty years since 1983 when the societies of the then divided Germany celebrated the anniversary of the Reformer. The traditions of Luther studies in Germany of the long twentieth century influenced by the surge of the myth of the nation state and its gradual overcoming were slowly dying away ${ }^{1}$.

New milestones in the social sciences formed a new perspective. The turn towards historical anthropology concentrating on the comprehensive research of the personality defined the starting positions of the generation of scholars of 1983. Their descendants today aspire to differentiate and summarize this vast material from their viewpoints.

The emergence of extreme opinions within the methodological framework is quite understandable. One of them is exemplified in a brilliant monograph by a Dutch historian Heiko Oberman (1930-2001), published in Berlin in the German language the year

1 There is extensive scholarly literature on this subject. The following works can be mentioned: Lutherforschung im 20 Jahrhundert / Hrsg. von R Vincke. Göttingen, 2004; Luther-Bilder im 20 Jahrhundert / Hrsg. von F. von Ingen, G. Labroussee. Amsterdam, 1984; Mühlhaupt E. Luther im 20 Jahrhundert. Aufsätze. Göttingen, 1982; Bornkamm H. Luther im Spiegel der deutschen Geistesgeschichte mit den ausgewählten Texten von Lessing bis Gegenwart. Göttingen, 1970. 
before the celebrations of $1983^{2}$. Another example can be found in a monumental work by a German colleague Heinz Schilling, forty years later. His «Martin Luther: Rebel in an Age of Upheaval» which has been recently translated into Russian, can be regarded as a reflection of the "turn", the synthesis of new insights engendered by the concept of confessionalization ${ }^{3}$. These books are separated not only by a new epoch, but also by new ideas. However, in methodological terms they manifest two practices of interpretation of Luther in postmodern time.

As far as Heiko Oberman's «Luther - Man between God and the Devil» is concerned, it can hardly be classified within any familiar genre after the first reading. The reader may wonder whether it is a combination of essays, a laborious scholarly treatise or some elements of theological studies. The reason of such eclecticism lies in the figure of the author.

Oberman has placed himself or, to be more precise, his pursuits of Luther, as a person in the book. Luther-monument, Luther-Reformer, Luther as a subject of the research disappears, and is substituted by the second half of 'self' of the author. They will accompany each other, arguing and trying to find mutual understanding until the last lines. On the part of the author there is eagerness to comprehend Luther's motives and thoughts, using and overcoming his own experience at the same time. As for Oberman's personal experience, it was tough and bitter: German occupation, hardships and bereavements in the adolescence and only much later - a successful career of a historian. The invitation to head the department of the late Middle ages and Reformation in the University of Tübingen, in the country responsible for the shock of his young age, marked a climax in his career. His fruitful and longlasting work signified a shift in himself - forgiveness of former enemies and new insights into the Reformer ${ }^{4}$..It is the perspective that matters: the epoch inside a person rebelling against the epoch. Obviously, before Oberman Luther had not always been examined only through the institutional prism. Suffice it to say that Catholic tradition had tried to discredit Luther's psychophysiological portrait until the middle of the twentieth century. However, it was Protestants as well as historians-Marxists who prevailingly looked upon Luther through social institutes. That is why, a biographical structure of the narration has become common: from birth to development, the history of the construction of the memorial named "Luther". Oberman radically departs from this tradition: he pursues only a personality and the origins of his motives. He rejects a biographical framework, views him initially through an epoch, all the time narrowing down the scope until the encounter with Luther as a person. Simultaneously he denies the constants of the epoch per se and social realities in their contemporary interpretation. In the year of Luther's death, neither new Church as an established institute, nor Lutheran church existed. The Reformation itself is not a German phenomenon since it swept across the structures of the universal empire. That was why its institutional destiny occurred in the Empire, not in Germany. The Reformation provoked consolidation of the old world, and was not perceived as the birth of something new. Its aims were not purely German: Luther considered his mission to be all-Christian since salvation remained a category of a universally

2 Oberman H. A. Luther. Mensch zwischen Gott und Teufel. München, 2016; Prokop’ev A. Iu., Lur'e Z. A. Liuter piat' vekov spustia. Razmyshleniia nad knigoi Khaiko Obermana // Proslogion. Problemy sotsial'noi istorii i kul'tury srednikh vekov i rannego novogo vremeni. 2017. Vol.3(1). P. 235-257.

3 Schilling H. Martin Luther: Rebell in einer Zeit des Umbruchs. Eine Biographie. München, 2016; Shilling Kh. Martin Liuter: buntar' v epokhu potriasenii. Moscow, 2017.

${ }^{4}$ See autobiographical notes: Oberman H.A. Zwei Reformationen. Luther und Calvin - Alte und Neue Welt. Berlin, 2003. 
Christian culture. His German language and his Germany served only as the base and the means for a great mission of preaching evangelization. Similarly, it was almost impossible to differentiate politics from faith: German princes, standing up for Luther, were guided by their roles of keepers of Christian concordance, assistants of the Church in the cause of future salvation ${ }^{5}$. The legacy of the past lied in their actions as well as in the ways of Luther's invention - through nominalism, Augustinian tradition and the Bible.

The reformer himself can't be perceived only through the consequences of his upbringing and conflicts with his father and stern mother ${ }^{6}$. Undoubtedly, Oberman aimed at the remains of the nationalist tradition. He understood a sharp contrast between what was revealed in his research and what was imposed on humanities and public thirty years prior to the publication of his book. Indeed, it was a slow and controversial process to remove the halo of a zealot of the nation destined to show a path to the future from $\mathrm{Lu}$ ther. This was not only due to some residual Nazi perceptions, but also because of the fact that Western German historiography after 1945 for a long time embraced Neo-rankeanism which espoused the priorities of the nation and the state, permanent pillars of social thought since the $19^{\text {th }}$ century ${ }^{7}$. Oberman consistently debunks the interpretations of the nation state but it is not enough for him: he also examines his hero introspectively, internally. The phenomenon of an individuum and personal reflections is pivotal to him. A gap between the old and the new in Luther has its roots in it. The changes are determined by transformations in Luther's inner world. However much these changes were defined by external conditions, it was him who had to make a final choice. The identification of two opposing opinions in his character's strivings is the top of introspective meticulousness of the scholar: aspiring to Christ and fear of Devil, who cannot be defeated by fleshly efforts and whose temptations cannot be avoided. Devil becomes a criterion and impetus for Luther's formation as a reformer: the more works of the devil, the closer the fulfillment of the Testament. Oberman turns the main enemy of the humankind into a key backstage hero of the earthly life of Luther, at first - imperceptibly, but with each section of his book more and more explicitly. The climax of the Reformation battles - the Diet of Worms in 1521 - turns out to be the climax in Luther's confrontation with Devil ${ }^{8}$.

In methodological terms this approach is impeccably Protestant. However, its consistent application paradoxically implied wider prospects. It motivated scholars to examine different lines of interconnectedness between the inner world of a person and his environment more closely, and in a wider sense - to reconsider people in the spiritual world of the late Middle ages and to recognize their opinions. The prevailing structural-social approach transformed in German historiography in 1950-1970s into a more familiar scheme "state and society". As far as Luther and reformation were concerned, it started to lose its predetermined criteria, greatly atomized and shifted to the level of historical anthropology 9

${ }^{5}$ Oberman H. A. Luther. Mensch zwischen... S. 15-99.

${ }^{6}$ Ibid. S. 100-134.

7 Concerning general issues: Iggers G. Deutsche Geschichtswissenschaft: eine Kritik der traditionellen Geschichtsauffassung von Herder bis zur Gegenwart. Wien, 1997. S.295-365; concerning Medieval studies: Goetz H. W. Moderne Mediävistik. Stand und Perspektiven der Mittelalterforschung. Darmstadt, 1999. S. 89-103.

8 Oberman H. A. Luther. Mensch zwischen... S. 249-258.

9 Theoretical aspects: Dülmen R. van. Historische Anthropologie. Entwicklung, Probleme, Aufgaben. Köln, 2001. 
It goes without saying that we are far from regarding Oberman as the pioneer of "anthropology" of Luther. Yet, a Dutch scholar was in line with the general changes in the social sciences. From the beginning of the 1970s in Germany, in the medieval and early Modern studies, in particular, the framework of structural history was already decaying and breaking into fragments revealing elements of personality underlying structural combinations ${ }^{10}$. Oberman does not completely reject the breakthrough in the new world achieved by Luther. Ultimately, the Reformation itself signified the beginning of the Modern time. However, his experience of gaining insight into the Reformer dealt a crushing blow to the old principles of statehood and forming nation, and impelled to see the eve and Luther himself nurtured by the Middle ages. With regard to this, his book could be interpreted in two ways: aiming at the future and at the same time calling for research of precursors, i.e. late Middle ages. A series of author's denials bravely vindicated the $15^{\text {th }}$ century as a self-sufficient epoch. Luther was gifted with a unique capability of discovering something new in himself and of finding a fresh, hard won perspective on salvation. However, this capability only made passive, conservative public life more conspicuous.

Thus, the author accentuated the alternative: either to connect Luther to a large degree to the past, making his doctrine a purely medieval product, or, to a greater extent, see the emergence of the new. Obviously, the author's activity as a head of the most important research institution influenced the creativity of his colleagues. The department he was in charge of initiated a major topic "Luther and the late Middle ages". Leaving the Federal Republic of Germany in 1984, a Dutch historian could be satisfied with his mission and work: he not only reconciled himself with the past but determined a clearer tendency in Luther studies, in line with new scholarly trends.

A monograph by Heinz Schiling is as cumulative as Oberman's book. It has been republished twice. However, the initial points of departure in these two books are different. Schilling had to reveal his insight into Luther, which accorded with his concept of confessionalization. It is quite appropriate to draw a comparison between this work and his earlier text "Germany 1517-1648. Breakthrough and crisis"11. Having been written on the basis of preceding essays concerning local and social issues, it focused on the society as a whole - through the framework and coordinates of the concept of confessionalization. A structuralist approach with an explicit touch of political history (as structuralists perceived it at the end of the $20^{\text {th }}$ century) undoubtedly prevails in it. However, it presents a wider range of processes and changes until the Peace of Westphalia and the end of the Thirty Years' War. In the monograph in question the emphasis of the study is placed on the person, and hardly because of the radical shift of perspective: until recently a Berlin historian has been writing about the consequences of confessional reorganization in a wide context of civilization. Furthermore, the methodological connections with traditional spheres - politics and power, state and society- have become more and more prominent. From the research of the power structures the attention has shifted to the issues of international relations, to the birth of state communities in Europe ${ }^{12}$.

10 Iggers G. Geschichtswissenschaft im 20. Jahrhundert. Ein kritischer Überblick im internationalen Zusammenhang. Göttingen, 2007. S. 86-101; Goetz H. W. Moderne Mediävistik. Stand... S. 106-117.

11 Schilling H. Aufbruch und Krise. Deutschland 1517-1648. Berlin, 1998.

12 We can refer to some works here: Schilling H. 1) Early Modern European Civilization und its Political and Cultural Dynamism. Hannover; London, 2008; 2) Konfessionalisierung und Staatsinteressen. Internationale Beziehungen 1559-1660. Paderborn, 2007; 3) Gab es in Europa um 1600 einen Konfessi- 
The table of contents and the first pages of the book reveal continuity of the aim and efforts. They are expressed in a succinct way in the preface to the Russian edition of the text: «The book is dedicated to a scholarly deconstruction of a German Protestant myth about Luther and to a reconstruction of genuine historical interconnectedness ${ }^{13}$. The restoration of the truth, as it is written further, is aimed at doing justice to the enemies of Luther, Catholic church and Catholic authorities of the Empire. The desire to vindicate the opposing side through reconstructed historical interconnections again shows conceptual foundations: the idea about an independent development of Catholic reform originated without any links with Luther's activity. Similarly, Oberman wanted a quick and complete removal of traces of miserable past from the perceptions of Luther. However, he had his own, very personal response to this task and he dedicated the whole book to it.

Schilling chose a strikingly different way. Instead of the introspectiveness of Oberman's approach, there comes external pressure. From the very beginning a renowned historian puts Luther like a tiny grain of sand in the complicated structures of European Christian world. Even the first chapter about 1483, the year of the Reformer's birth, triggers a detailed discussion about late medieval Europe, about social, political and economic movements, which were gradually changing the image of the West. Oberman seems to resort to the same device in the first section of his book. Yet, the Dutch historian uses it to vigorously deny all the changes: the Reformation flew through the veins of the old world. In contrast to him, Schiling shows a panorama of sweeping changes. They revealed the imbalance of development and explicit regionalism: the Atlantic turned into a waterway of the future, whereas Central Germany represented a backward provincial region. The peculiarity of its life finally engendered the phenomenon of Luther who did not understand or did not want to understand the development outside his native area.

This start is of paramount importance for Schilling: it enables to explain the subsequent isolation of German Reformation, which did not manage to spread to the south and to the west across the Alps and Rhine, let alone the Mediterranean region. Indeed, the difference of the modes of life and dynamics of development ensured the place for Catholic reformation.

Furthermore, at the end of the book the consequences of the Reformation and Luther's activities are outlined. It can be called a guidebook to the history of the early Modern time. The historian explicitly tries to incorporate Luther into global perspectives. It is due to the priorities of a major conceptualist: first and foremost, the discussion revolves around the state and politics, around the organization of society. The individual seems to take second place and disappears in the ocean of roaring processes ${ }^{14}$. We can understand the author. Yet to what extent is this experience successful? Without any doubts, we cannot deny the mastery of a famous historian of processing the material, his sound knowledge of sources, the desire to rely on contemporary works of his colleagues, and, finally, the aspiration to present a complete picture. The style of Schilling's writing is above criticism: he avoids ponderosity and often tries to make very complex theoretical material comprehensible. However, the author has to be consistent in covering the topic. Apparently, this formidable task - from the viewpoint of 'confessionalization' and from other general

onsfundamentalismus? Die Geburt des internationalen Systems in der Krise des konfessionellen Zeitalters // Jahrbuch des historischen Kollegs. 2005. München, 2006. S.69-93.

13 Shilling Kh. Martin Liuter... P.XI.

14 Schilling H. Martin Luther... S. 612-638. 
perspectives to demonstrate the life and struggle of the Reformer - makes the author go through a painful ordeal. He is forced to connect the period of his character's life path, all his circumstances, with general structural issues and to be torn between two models of generalization - between the confessional multipolarity and the correlation between the "medieval" and the "modern". Failures are unavoidable.

The author is often unable to strike a balance and every time to leave a place for the personality of Luther, and it is hardly possible at all, even considering six hundred pages of the book. There are inevitable sacrifices: the development of Luther until 1517 comprises only one fourth of the text. What a contrast to Oberman's text where the description of the spiritual precursors and Luther's personal way to Christ takes up almost half of the narrative. An elaborate and abundant in emotional details description of Luther's family life after 1524 is abruptly interrupted by the scenes of social struggle. The further, the less is left of the figure of the Reformer until he disappears. The appearance of each new character, be it Emperor Charles V, the elector of Saxony, Frederick the Wise, or the description of Wittenberg and Rome, Peasants' war or the Diet in Worms, causes the author to turn to wordy general speculations, in which the main character is given less and less attention. The closer the resolution is, the more place is taken by descriptions of external world and wide, often didactic, generalizations.

However, the correlation between "figure and history" comprises only one side of the coin. Having set the objective to free the Reformation from the halo of revolution and revolutionism in keeping with the Protestant tradition, Schilling has to do justice to the Catholic Church - in accordance with the concept of confessionalisation. However, the two-fold task is very challenging. Only in some places the author, as if suddenly remembering, mentions the correlation between the Protestant and Catholic movements. It is only while describing Luther's presence in Rome in 1510 that he can afford speculations concerning the idea of the Catholic reform, and later - in the section about the criticism of the absolution of sins - in the context of the events of $1517^{15}$. In these parts there is nothing more than the desire for an unbiased analysis of the ideas of Catholic opponents. A feeling of a great alternative from Rome, of the parallelism of the movement, does not arise. The alternative is outlined in a metaphysical way, in short essays, for example, about new orders and communities of 1520s, including Jesuits. Only in the end, in the comparison between two models of pious deaths - of Luther and of his main opponent, Emperor Charles, and, finally, in the summarizing sections, the inevitability of the schism and objectivity of Catholic alternative to Lutheranism is mentioned ${ }^{16}$. The imbalance could have been redressed if the author had revealed the "Catholic" side of Luther's soul, the aspects which still provoke the debate among the historians. In other words, the author should have raised the issue of Luther as a Catholic and traced the evolution of the Reformer in this sense before and after 1517-18. Undoubtedly, the discourse concerning the individual would have become more profound, and the structure of analysis would have been counterbalanced. On the contrary, especially after the description of the Diet of Worms there are scenes depicting struggle and speculations of those sides in Luther's ideas which separated him from Catholicism.

Obviously, Schilling wants to express his own viewpoint on all the mentioned details but often repeats the already known facts, such as social position of Luther's mother, the

15 Ibid. S. 90-99.

16 Ibid. S. 604-611. 
date of Luther's journey to Rome, or a detailed comment on why "ninety-five theses" were not posted on the doors of Wittenberg church on a memorable day of the $31^{\text {st }}$ of October. On the one hand, it can be attributed to the thoroughness worth of a great historian. On the other hand, constant repetition of familiar information obscures a conceptual framework.

The resultant feeling is ambivalent. It is difficult to comprehend not only the development of Luther's inner world, but also the whole picture: individual and society, Catholic and Protestant alternatives. Both facets are too overshadowed by the excursuses into historical interconnectedness and forthcoming prospects. The dimension of historical anthropology vividly and consistently presented by Oberman is fundamentally deformed by Schilling. Everything is sacrificed to the global structures. That is why we can feel the "protest" of the personality ruthlessly confined in a greater outside world. Probably, the author himself in an attempt to enhance a global, general segment soon comes back to the basics.

His monograph "1517. One-year world history» tries to dissolve Luther in the roaring flow of movements on the eve of the Reformation ${ }^{17}$. The gold of the New World, geographical expansion, technological and agricultural progress, changing structures of the society - everything serves as confirmation of the changes taking place at the same time with the Reformation but independently from it. Again, even though implicitly, Schilling returns to an old topic: to debunk the halo of revolutionism of only the Protestant reformation and Luther. The author demonstrates the processes which, according to him, indicate the emergence of the Modern time together and along with Luther but not due to him. The book resembles a wordy summary or even a research pamphlet. However, it is more "ideologically" complete, unlike "Martin Luther", at least, because there is no place there for a personality at all.

Schilling's principal work reflects one of the major difficulties of today's social sciences: a painful pursuit of a compromise between a structure which is atomized to the level of a certain person and the experience of great synthesis of structures per se; i.e. macro- and microhistory in balance and controversy.

Will a reversal be more productive: a rigorous, methodological integration of micro-level into the world of great structures? How fruitful, as far as this question is concerned, are the works about Luther, which can be placed in between the extremes of Oberman and Schilling. Without reviewing the abundance of such books, we would like to allude briefly to Volker Leppin's work "Another Reformation. Mystical roots of Luther", the second edition of which was published in 2017.

"Was Luther at the beginning?" No, he was not. The Late Middle ages were at the beginning of his spiritual self: these are the question and the answer addressed by a young and well-known historian of Protestant theology in his two hundred-page-book. The introduction is succinct: Luther is alien to $\mathrm{us}^{18}$. He is far from us as a person fostered by the epoch in which he was born - the Late Middle ages. The author presents a series of speculations very consistently accentuating the ideological orientation of Oberman's book which was manifested in the dilemma - Luther was shaped by the Middle ages, but they gave place to the Modern time in himself.

17 Schilling H. 1517. Weltgeschichte eines Jahres. München, 2017.

${ }^{18}$ Leppin V. Die fremde Reformation. Luthers mystische Wurzeln. München, 2017. S.9-10. 
In short chapters Leppin describes why Luther was formed and remained predominantly a mystic, typical of the $15^{\text {th }}$ century. He made friends with Johann Staupitz who influenced him, particularly as far as theology of Christ is concerned. From Staupitz the line of continuity is traced further back, to those who made an impact on the tradition of Hermits of St. Augustine. One should not forget the authorities of bygone years, Johann Tauler and Saint Bernard of Clairvaux, whose perception of sin and repentance shaped Luther's understanding of salvation ${ }^{19}$. Special attention is devoted to Luther's acquaintance with the anonymous "German theology", a brilliant product of the mystical culture of the $14^{\text {th }}$ century $y^{20}$. The notion of repentance as everyday embodiment of the spiritual life of people, which was completely independent from ecclesiastical rites, was a principal aspect. Furthermore, studies by mystics and his own personal spiritual experience more and more convinced Luther of absolute sinfulness of the humankind and the necessity of pursuit of salvation only in the love of God manifested in Christ. Thus, he was ready to depart from the tradition of scholasticism, from Aristotelism in Thomist interpretation, which regarded a human being as an act of creation and saw the image of God in him. Henceforward, not divine elements in man, but only mercy and love of God manifested in the act of faith can contribute to the salvation ${ }^{21}$. A consistent and stark contrast between God and man originated from Luther's awareness of the mystical experience of his predecessors.

Even before Leppin, all these sources of influence had not escaped the attention of scholars. However, the author emphasizing the issue of repentance connects all of them together. This issue gave young Luther a powerful impetus of the Middle Ages.

New forms of scholarly interaction through the communities of humanists and scholars, through "sodalites", facilitated the process of gaining insight into the mystical legacy, enriched some aspects of Luther's theology nurtured by mysticism. The printed version of the sermon spread quite familiar medieval ideas in a new form ${ }^{22}$. For Leppin, Luther in both 1517 in his theses against indulgence and in Augsburg in the dispute with cardinal Cajetan is the same monk who expounded a hard-won doctrine influenced by mystical theology.

As far as the separation from Rome is concerned, Leppin is probably more consistent than his predecessors in combining the elements of accidentality and basic foundation. Two tragic accidents were associated with the beginning of the schism: the personality of Silvester Mazzolini from Piedmont (more known as Prierias 1456-1527), who was put in charge of evaluation of Luther's theses from the perspective of the dogma, and a famous cardinal Cajetan (1469-1534), who was sent to Augsburg for a personal dialogue with the Augustinian. Prierias, who shared some notions by Staupitz and ,correspondingtly, those by Luther, found attacks at the authority of the Church in Luther's theses, i.e. an ecclesiological aspect of Luther's theology at the time. According to Prierias, for the Church, as for the community of worshippers, its visible head is implicitly manifested in the figure of Roman Apostolic in the same way as Christ is the head of the invisible Church. Unoriginal though the argument may seem, it was unusually intensified by the learned Prelate: he amplified it to the postulate of papal in fallibility akin to the infallibility of Christ, although

\footnotetext{
19 Ibid. S. 11-33.

${ }^{20}$ Ibid. S. 39-43.

${ }^{21}$ Ibid. S. 78.

22 Ibid. S. 44-54.
} 
the Catholic Church justified it only in 1870, whereas in the XVI century this idea was not emphasized at all. Prierias not only asserted that the Pope was capable of assisting all the dead in the future salvation, but also extended the possibility of his intercession on behalf of those in purgatory. It was a novelty to the ecclesiastical law of the period. Willingly or unwillingly, Prierias considerably radicalized the conflict with Luther, having transferred it in the "political context" as it was already concerned with the authority of the Pope ${ }^{23}$.

As regards Cajetan, his obstinacy in Augsburg, where he refused to cooperate with Luther and was irritated by the communication with the Reformer, negatively contributed to the escalation of the conflict, given that Rome anticipated the changes on the Emperor's throne $e^{24}$.

However, centralism and the authority of the Church was what Rome could not abandon and what underlay the schism. A different position was unacceptable for the spiritual world of the Catholic Church. Furthermore, the triumph over the ideas of conciliarity at the end of the $15^{\text {th }}$ century only stressed the decisiveness of the Papacy to stand their ground.

Leppin is not only consistently anthropocentric but also presents the Catholic Church and its structures always together and in parallel to Luther. The undoubted merit of Leppin's book, especially in contrast to fragmentary excursuses by Schilling, is that there are comparisons between Catholic church and Luther, and clarifications. According to Leppin, "transformation" rather than discovery or a radical breakthrough in the development of Luther's dogma is essential. Only gradually did an Augustinian monk Luther turn from a typical mystic into the founder of a new Church. Leppin exemplifies the beginning of the process with the treatises concerning Eucharist in 1519 and completes the narration demonstrating the scenes of new political reality - the Knight's revolt led by Sickingen, Peasants' War and the Princely Reformation ${ }^{25}$. In the epilogue he stresses the paradox again: even in the $20^{\text {th }}$ century the classics of Protestantism persistently deny the mystical foundations of the evangelicalism ${ }^{26}$.

Leppin's oeuvre can be relatively classed among those works in Luther's anthropology which try to closely connect the Reformer with the past, with the world of the Late Middle ages. These works are concentrated on the consecutive stages of the development of an individuum, on the aspects which are lacking in major civilizational generalizations ${ }^{27}$. It might be possible to anticipate a barrage of criticism for such a strong emphasis on the Middle ages. The books by Leppin were attacked by the experts on the $16^{\text {th }}$ century, whose interests revolve not only around the development of Luther as a reformer, but also around the Evangelical Church and its spiritual world at a late stage - during the 'late' years of Luther or after Luther. Volker Leppin met with harsh criticism from Thomas Kaufmann, whose biography of Luther was published almost simultaneously with Leppin's books. Kaufmann is not only a historian, but also a practicing theologian. It is essential for him to find in Luther an impulse for creative development of current evangelical theology,

23 Ibid. S. 89-94.

24 Ibid. S. 97-101.

25 Ibid. S. 117-185.

26 Ibid. S. 209-216.

27 Apart from the discussed work by Leppin: Leppin V. Die Reformation. Darmstadt, 2013; Leppin V. Martin Luther. Darmstadt, 2010; Leppin V. Das Zeitalter der Reformation. Eine Welt im Übergang. Darmstadt, 2009. 
the symbol of mobilization and renewal of the church which is capable of responding to today's challenges without losing its dogmatic identity.

He severely criticizes the idea of the "transformation" of mystical Luther, and also doubts the medieval origins of the evangelical Church, which is emphasized too rigorously by a "tragic knight from Tübingen", how he calls Volker Leppin in the review of his book $^{28}$. Kaufmann finds in the personality of Luther the aspects which unite him with his predecessors, including Oberman, - breakthrough, gift, revelation. The new was born within Luther himself, and a social impulse of his activities shaped a new environment. Obviously, it is impossible not to notice the legacy of late medieval foundations in Luther. However, since 1517, from the first years of his activity, to a greater or lesser extent, it was realized through struggle and constant resistance, which meant the schism and the formation of a new Church and society ${ }^{29}$.

On the eve of the anniversary of the Reformation it is possible to celebrate the anniversary of an arduous journey made by the historiography of Luther - even its last forty years are worth a separate study. Between the extreme viewpoints of anthropological insights into the personality of Luther and sweeping generalizations there are tendencies tracing Luther entirely back to the spiritual world of the Middle ages (Volker Leppin) and, on the contrary, connecting his activities to the new reality of the $16^{\text {th }}$ century (Thomas Kaufmann). However, the abovementioned scheme itself is only an ideal construct comprising a large number of aspects explicit in a variety of other works, which also deserve a special attention.

\section{References}

Bornkamm H. Luther im Spiegel der deutschen Geistesgeschichte mit den ausgewählten Texten von Lessing bis Gegenwart. Göttingen, Vandenhoeck und Ruprecht Publ., 1970, 469 S.

Goetz H.W. Moderne Mediävistik. Stand und Perspektiven der Mittelalterforschung. Darmstadt, Wissenschaftliche Buchgesellschaft Publ., 1999, 12 S.

Dülmen R. van. Historische Anthropologie. Entwicklung, Probleme, Aufgaben. Köln, Böhlau-Verlag Publ., 2001, 135 S.

Iggers G. Deutsche Geschichtswissenschaft: eine Kritik der traditionellen Geschichtsauffassung von Herder bis zur Gegenwart. Wien, Böhlau Publ., 1997, 398 S.

Iggers G. Geschichtswissenschaft im 20. Jahrhundert. Ein kritischer Überblick im internationalen Zusammenhang. Göttingen,Vandenhoek und Ruprecht Publ., 2007, 175 S.

Kaufmann T. Martin Luther. 2. Auflage, München, C. H. Beck Print., 2010, 128 S.

Kaufmann T. Erlöste und verdammte: eine Geschichte der Reformation, 3.Auflage. München, C. H. Beck Print., 2016, 508 S.

Kaufmann T. Geschichte der Reformation in Deutschland 2 Auflage. Berlin, Verlag der Weltreligionen im Inselverlag Publ., 2009, 954 S.

Leppin V. Martin Luther. Darmstadt, Primus Verlag Publ., 2010, 195 S.

Leppin V. Die fremde Reformation. Luthers mystische Wurzeln. München, C. H. Beck Print., 2017, 247 S.

Leppin V. Das Zeitalter der Reformation. Eine Welt im Übergang. Darmstadt, Wissenschaftliche Buchgesellschaft Publ., 2009, 160 S.

${ }^{28}$ Kaufmann T. Ein Gespenst namens Protestantismus. Reformatoren-Zwerge und ein Schrumpfgermane: Drei neue Bücher über Martin Luther werfen die Frage auf, warum 2017 eigentlich gefeiert wird URL: http://www.faz.net/aktuell/feuilleton/buecher/rezensionen/sachbuch/buecher-zum-lutherjahr-ein-gespenst-namens-protestantismus-14133169.html (accessed 26.10.2017).

29 These ideas are expressed in both the biography of Luther written by Kaufmann and in his general works concerning the history of the Reformation: Kaufmann T.: 1) Geschichte der Reformation in Deutschland. 2 Auflage. Berlin, 2009; Kaufmann T. Martin Luther. 2. Auflage. München 2010; 2) Erlöste und verdammte: eine Geschichte der Reformation; 3) Auflage. München, 2016. 
Leppin V. Die Reformation. Darmstadt, Wissenschaftliche Buchgesellschaft Publ., 2013, 144 S.

Luther-Bilder im 20 Jahrhundert. Hrsg. von F. von Ingen, G. Labrousse, Amsterdam, Rodopi Publ., 1984, $266 \mathrm{~S}$.

Lutherforschung im 20 Jahrhundert. Hrsg. von R. Vincke. Göttingen, Vandenchoek und Ruprecht Publ., 2004, 290 S.

Mühlhaupt E. Luther im 20 Jahrhundert. Aufsätze. Götiingen,Vandenhoek und Ruprecht Publ., 1982, 469 S.

Oberman H. A. Luther. Mensch zwischen Gott und Teufel. München, Pantheon Ausgabe Publ., 2016, 446 S.

Oberman H. A. Zwei Reformationen. Luther und Calvin - Alte und Neue Welt. Berlin, Siedler Verlag Publ., 2003, 320 S.

Prokopiev A. Yu. Lurie Z. A. Lyuter pyat vekov spustya. Razmishleniya nad knigoy Kheyko Oberman. Proslogion. Studies in Medieval and Early Modern Social History and Culture, 2017, vol. 3, no. 1, pp. 235-257. (in Russian)

Schilling H. Aufbruch und Krise. Deutschland 1517-1648. Berlin, Siedler Taschenbuch Publ., 1998, 508 S.

Schilling H. Early Modern European Civilization und its Political and Cultural Dynamism. Hannover, London, The Menahem Stern Jerusalem Lectures, 2008, 144 p.

Schilling H. Konfessionalisierung und Staatsinteressen. Internationale Beziehungen 1559-1660. Paderborn, Schöningh, Publ. 2007, 684 S.

Schilling H. Gab es in Europa um 1600 einen Konfessionsfundamentalismus? Die Geburt des internationalen Systems in der Krise des konfessionellen Zeitalters, Jahrbuch des historischen Kollegs, 2005, S. 69-93.

Schilling H. 1517. Weltgeschichte eines Jahres. München, C. H. Beck Print., 2017, 364 S.

Schilling H. Martin Luther: Rebell in einer Zeit des Umbruchs. München, C. H. Beck Print., 2016, 728 S.

Schilling Kh. Martin Luther. Buntar' v epochu peremen. Moscow, Isdatelstvo bogoslovskogo instituta, 2017, 710 p. (in Russian)

Received: 01.09.2017

Accepted: 30.03 .2018 